\title{
AVAILABILITY OF SOIL WATER IN THE INITIAL DEVELOPMENT OF PIGEON PEA CULTIVATED IN A CONTROLLED ENVIRONMENT
}

Edna Maria Bonfim Silva ${ }^{1}$, Gislane Renata Frigo ${ }^{2}$, Carolina Silva Alves dos Santos $^{3}$, Maria Débora Loiola Bezerra $^{4}$, Tonny José Araújo da Silva

\begin{abstract}
The pigeon pea (Cajanus cajan) is an erect legume used for various purposes, such as improving plant and soil reclamation. The objective of the present study was to evaluate the development of pigeon pea cv. IAPAR 43 Arata subjected to different soil water availabilities. The experiment was conducted in a greenhouse in a completely randomized design with six soil water availabilities $(20,40,60,80,100$ and $120 \%$ of the maximum capacity of water retention in the soil) and six replications. Soil moisture at field capacity was $0.24 \mathrm{~cm}^{3} \mathrm{~cm}^{-3}$. Plastic pots were used with $5.0 \mathrm{dm}^{3}$ of capacity and each contained three plants. Soil moisture was maintained gravimetrically. The parameters analyzed were soil pH, SPAD reading, number of leaves and dry weight of leaves, stems and roots. The results were submitted to analysis of variance with regression testing considering $5.0 \%$ of probability and all were fitted to quadratic regression model. The higher results for soil $\mathrm{pH}$ and SPAD readings were observed in 80 and $31.78 \%$ water availability, respectively. The results that offered the highest number of leaves and dry weight of leaves, stems and root were between 51.82 and $59.02 \%$ of the maximum soil water retention capacity. The pigeon pea cv. IAPAR 43 Arata is sensitive to drought and also to saturated soil conditions, where the best water availability for this crop is in the range from 51.82 to $59.02 \%$.
\end{abstract}

Keywords: Cajanus cajan, field capacity, maintaining soil moisture

\section{RESUMO}

\section{DISPONIBILIDADE DE ÁGUA DO SOLO NO DESENVOLVIMENTO INICIAL DE FEIJÃO GUANDU CULTIVADO EM AMBIENTE CONTROLADO}

O feijão guandu (Cajanus cajan) é uma leguminosa com porte ereto utilizado para diversos fins: como planta melhoradora de solos e na recuperação de áreas degradadas. Objetivou-se com o presente estudo, avaliar o desenvolvimento do feijão guandu cv. IAPAR 43 Aratã submetido a disponibilidades hídricas do solo. O experimento foi conduzido em casa de vegetação com delineamento experimental inteiramente casualizado, sendo seis disponibilidades hídricas (20; 40; 60; 80; 100 e 120 \% da capacidade máxima de retenção de água no solo) e seis repetições. Foram utilizados vasos plásticos com capacidade para $5 \mathrm{dm}^{3}$ com três plantas. A umidade do solo foi mantida por gravimetria. Analisou-se pH do solo, leitura SPAD, número de folhas, massa seca da parte aérea e raiz. Os resultados foram submetidos à análise de variância e teste de regressão, ambos a 5\% de probabilidade, todos ajustaram-se ao modelo quadrático de regressão. Os maiores resultados para $\mathrm{pH}$ do solo e leitura SPAD foram observados nas disponibilidades hídricas de 80 e 31,78 \%, respectivamente. As que proporcionam maiores número de folhas, massa seca da parte aérea e de raiz estão entre 51,82 a 59,02 \% da capacidade máxima de retenção de água do solo. O feijão guandu cv. IAPAR 43 Aratã mostra-se sensível ao déficit hídrico e também ás condições de solo saturado, a melhor disponibilidade hídrica para essa cultura está na faixa de 51,82 a 59,02 \%.

Palavras-chaves: Cajanus cajan. Capacidade de campo. Manutenção de umidade do solo.

Recebido para publicação em 24/11/2013. Aprovado em 02/09/2014.

1 - Zootecnista, Profa. Adjunto, Programa de Pós Graduação em Eng. Agrícola, ICAT-UFMT- Rondonópolis. embonfim@hotmail.com

2 - Biologa, Mestre em Engenheira Agrícola, Instituto de Ciências Agrárias e Tecnológicas- ICAT-UFMT- Rondonópolis

3 - Eng. Agrícola, Mestre em Engenheira Agrícola, Instituto de Ciências Agrárias e Tecnológicas- ICAT-UFMT- Rondonópolis

4 - Eng. Agrícola, Mestre em Engenheira Agrícola, Instituto de Ciências Agrárias e Tecnológicas- ICAT-UFMT- Rondonópolis

5 - Eng. Agrônomo, Prof. Associado, Programa de Pós Graduação em Engenharia Agrícola, ICAT-UFMT- Rondonópolis 


\section{INTRODUCTION}

The pigeon pea (Cajanus cajan (L.) Mill sp.) is a legume, native to tropical West Africa, widely used as green manure and with productive potential of dry matter for soil cover (BELTRAME;RODRIGUES, 2008). It was introduced in Brazil by the slave route from Africa and became extensively distributed and semi-naturalized in the tropical region, becoming an important source of human food (AKANDE, 2007).

The bean crop has great importance at the global and national levels. In Brazil, it is grown by small, medium and large farmers, with total annual production of 3.4 million tons (CONAB, 2010). For farmers it presents low cost production that is directly reflected on profit activity and improvements to soil fertility, resulting from the ability of this culture for biological nitrogen fixation (MARIN et al., 2004).

The pigeon pea can be used for various purposes, such as green manure, plant soil conditioner, degraded area recovery, renovation of pastures and in food and feed. For subsistence agriculture in semi-arid areas this leguminous vegetable has a long history and its ability to economically produce in soils with hydric deficits makes it an important crop for agriculture dependent on rain.

Green manure is a technique that consists of the cultivation of native or introduced species, grown in rotation or intercropped with crops of economic interest. These species may be annual, perennial and semi-perennial, and therefore cover the ground during certain periods or throughout the year (CALEGARI et al., 1993). After being mowed, they may be incorporated into or maintained in coverage on the soil surface.

The main agronomic characteristics to consider when choosing a green manure for use in agricultural systems are: high yield and seed weight cycle compatible with the production system, simple planting and harvesting, low susceptibility to diseases and pests, rooting depth, aluminum tolerance, extraction efficiency and nutrient cycling, high $\mathrm{N}_{2}$ fixation, drought tolerance, efficient control of weeds and nematodes, thereby increasing the productivity of subsequent crops (CARVALHO, 2010).

According to Nene and Sheila (2000), the pigeon pea is a crop of potential interest for green manure, by presenting a deep and extensive root system that makes it able to tolerate water stress and favors the disruption of compacted layers in the soil, and for this reason it is called a biological plow, and has been highlighted with respect to improvements in soil fertility (ALCÂNTARA et al., 2000). This crop promotes aeration and water infiltration into the soil, allowing for greater penetration of roots (LAL, 1986).

The pigeon pea is even being considered a rustic plant tolerant to water stress, which has also hampered its development when subjected to environments with low water availability. The decrease in productivity prevents photosynthesis, because water is a basic component of the reaction and is also responsible for maintaining transpiration which is essential for the permeability of carbon dioxide in mesophyll (BUCHANAN et al., 2000).

The Agronomic Institute of Paraná - IAPAR launched to market in 1990 an undersized variety called Early IAPAR $43 \mathrm{hp}$. Aratã whose yield varies from 1000 to $2000 \mathrm{~kg} \mathrm{ha}^{-1}$ (MIZUBUTI et al., 2000). This cultivar has been used as a green manure alternative; however, there is a need for studies on its resistance to water stress conditions.

The low soil water availability is a limiting factor in bean production, especially in the three critical stages that are germination, flowering and grain filling (SORATTO et al., 2003). Thus plant growth is limited by water and depends on the available quantity of this resource and its efficiency usage by plants. In water stress conditions, several physiological processes change, such as photosynthesis, stomatal conductance, abscisic acid production, leaf abscission and osmotic adjustment (TAIZ;ZEIGER, 2004). The pigeon pea is a hardy crop, reaching significant dry matter yield in water stress conditions.

Thus, the aim of the present study was to evaluate the initial development and production of the undersized pigeon pea IAPAR $43 \mathrm{cv}$. Aratã under the influence of soil water availability.

\section{MATERIAL AND METHODS}

The experiment was conducted in a greenhouse, during the period from September to December, 
Table 1. Chemical and textural analyses of soil samples at 0-20 cm under Cerrado vegetation, RondonópolisMT, 2012

\begin{tabular}{|c|c|c|c|c|c|c|c|c|c|c|c|c|c|}
\hline $\mathrm{pH}$ & $\mathrm{P}$ & $\mathrm{K}$ & $\mathrm{Ca}$ & $\mathrm{Mg}$ & $\mathrm{Al}$ & $\mathrm{H}$ & CTC & $\mathrm{MO}$ & $\mathrm{V}$ & $\mathrm{m}$ & Areia & Silte & Argila \\
\hline $\mathrm{CaCl}_{2}$ & \multicolumn{2}{|c|}{$\mathrm{mg} \mathrm{dm}{ }^{-3}$} & & .......... & $\mathrm{mol}_{\mathrm{c}}$ & ${ }^{-3} \cdots$ & ........ & $\mathrm{g} \mathrm{kg}^{-1}$ & \multicolumn{2}{|c|}{ …....\%........ } & \multicolumn{3}{|c|}{$\ldots \ldots \ldots \ldots . \mathrm{g} \mathrm{kg}^{-1} \ldots \ldots \ldots \ldots \ldots$} \\
\hline 4.1 & 1.1 & 47 & 0.2 & 0.1 & 1.0 & 4.7 & 6.1 & 19.7 & 6.9 & 70.4 & 575 & 50 & 375 \\
\hline
\end{tabular}

2012. The experimental design was completely randomized with six soil water availability levels $(20,40,60,80,100$ and $120 \%$ of the maximum capacity of soil water retention) and six replications. The soil water availability of $120 \%$ of the maximum soil water retention corresponds to the saturated soil condition (waterlogged). Soil moisture at field capacity was $0.24 \mathrm{~cm}^{-3}$.

The pigeon pea cultivar analyzed was IAPAR 43 Arata with small size, short life cycle, grown in plastic pots with a volume of $5 \mathrm{dm}^{3}$, and arranged in approximately $30 \mathrm{~m}^{2}$ in a completely randomized design. The Oxisol soil was collected at $0-20 \mathrm{~cm}$ in an area cultivated with Cerrado vegetation and chemical and particle size characterization was performed (Table 1) according to EMBRAPA (1997), in the region of Rondonópolis-MT.

The soil correction was performed to raise the base saturation to $60 \%$, using lime with $80.3 \%$ of total neutralization (SOUZA; LOBATO, 2002). After soil correction, which occurred in a period of 30 days, 20 seeds were sown per pot. Seven days after plant emergence the plants were thinned resulting in three plants per pot.

The fertilizer for crop establishment was performed using nitrogen, phosphorus and potassium in doses of 50,200 and $80 \mathrm{mg} \mathrm{dm}^{-}$ ${ }^{3}$, respectively, where the sources were urea, superphosphate and potassium chloride.

The maximum soil water capacity or field capacity was determined in a laboratory by the gravimetric method according to Bonfim-Silva et al. (2011a). Maintenance of soil moisture was performed daily by weighing the pots of all plots and replacing water transpired to the value corresponding to the percentage of soil water available, for each treatment in the experimental units.

The experimental evaluation was performed 30 days after plant emergence. The variables analyzed were: soil $\mathrm{pH}$ in $\left(\mathrm{CaCl}_{2}\right)$, SPAD index, number of leaves, dry weight of leaves and root. The fresh leaves and roots were placed in paper bags and dried in a forced air circulation oven at $65{ }^{\circ} \mathrm{C}$ until constant weight and then were weighed on an analytical balance. Determination of chlorophyll content was performed indirectly by the SPAD index using a portable chlorophyll meter SPAD 502 (MINOLTA CAMERA, 1989). These readings were performed on five leaves in each experimental unit to obtain the means of each experimental unit.

The results were submitted to analysis of variance and when significant the regression test at $5 \%$ probability was applied by means of the statistical software SISVAR (FERREIRA, 2008).

\section{RESULTS AND DISCUSSION}

Soil $\mathrm{pH}$ was significantly influenced by soil water availability by adjusting the quadratic regression model (Figure 1). The greatest $\mathrm{pH}$ was observed in $80 \%$ of the maximum soil water retention.

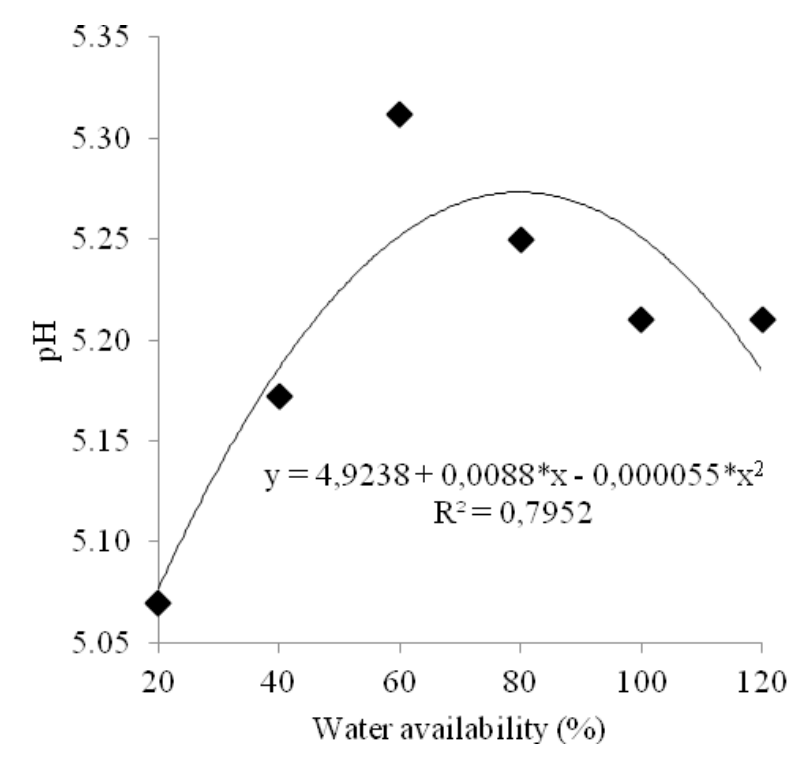

Figure 1. $\mathrm{pH}$ of the soil cultivated with pigeon pea cv. IAPAR 43 Aratã subjected to different levels of soil water availability. * Significant at $5 \%$. 
When well managed the pigeon pea contributes positively to increase the effective exchange capacity loads, as well as decrease the levels of aluminum in recycling capacity and mobilization of nutrients (CALEGARI et al., 1993). In this experiment, the $\mathrm{pH}$ most favorable for development of the culture was obtained at approximately $80 \%$ of the maximum water retention in the soil.

Dias et al. (2011), in studies with leguminous soybeans, crude, mucuna and pigeon pea, observed a higher $\mathrm{pH}$ when compared with the control without coverage, demonstrating that from the decomposition of plant residues from the leguminous vegetable may cause a decrease in soil acidity. Regarding the experiment, the $\mathrm{pH}$ which presented the best results for the cultivation of pigeon pea in a controlled environment was obtained in water availability of $80 \%$.

The SPAD index of pigeon pea was significantly influenced by soil water availability, fit to the quadratic regression model. The maximum SPAD index (52.83) was observed in $31.78 \%$ of available soil water (Figure 2). These results corroborate with those of Bastos et al. (2012) who when working with two cowpea cultivars subjected to water deficit observed maximum total chlorophyll contents of 58 and 69 , respectively.

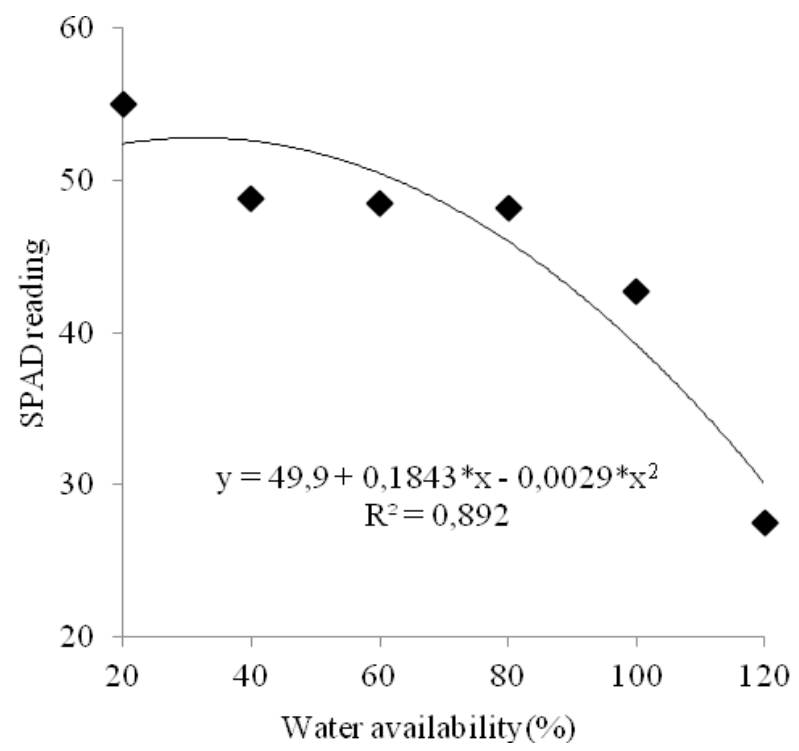

Figure 2. SPAD index of pigeon pea cv. IAPAR 43 Aratã subjected to different levels of soil water availability. ${ }^{*}$ Significant at $5 \%$.
According to Santos et al. (200), working with cowpea beans subjected to water levels of 60 and $100 \%$ of field capacity, the highest SPAD index (65.36) was observed in $60 \%$ of soil water availability. Bonfim-Silva et al. (2011a), cultivating three species of grasses, found the highest SPAD index values in soil water contents greater than 60 $\%$ of the maximum water retention of the soil.

The number of leaves the pigeon pea was significantly influenced by soil water availability, fit to the quadratic regression model. The highest number of leaves was observed in soil water availability of $55.53 \%$ of the maximum capacity of soil water retention (Figure 3 ).

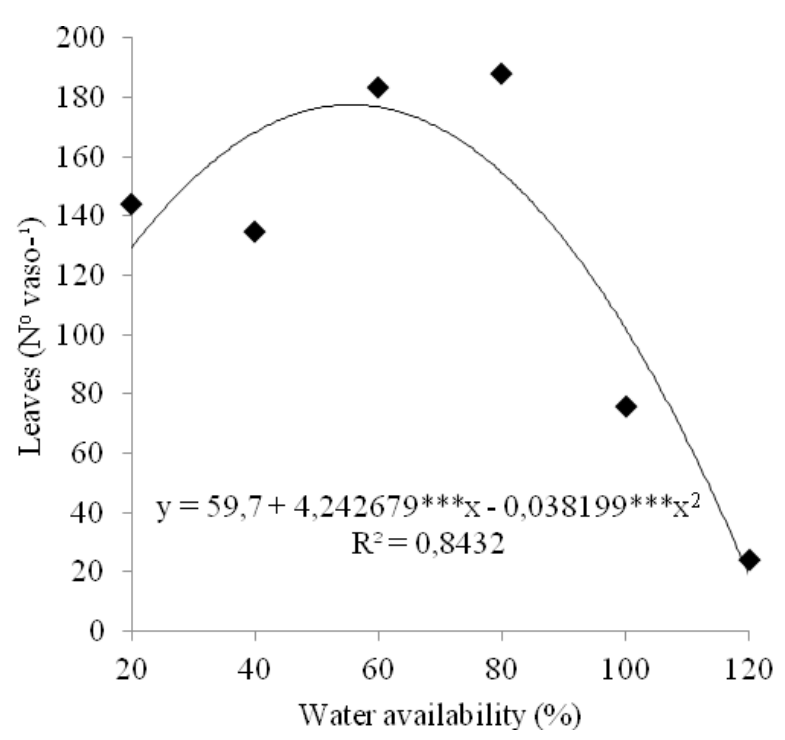

Figure 3. Number of leaves of pigeonpea cv. IAPAR 43 Aratã subjected to different levels of soil water availability. *** Significant at $0.1 \%$

Increased soil water availability reduced the development of pigeon pea, decreasing the number of leaves of legumes in soil water available above $60 \%$. Drought also influenced the development of plants so that the numbers of leaves was below that considered optimal for the experiment.

According to Oliveira et al. (2003), in beans the factors number of leaves, number of pods per plant and number of flowers showed relationships with grain/plant yield, and these characteristics may be important in selecting plants for increased production of grains. 
Silva et al. (2009), cultivating beans and correlating the number of leaves with other morphological characteristics of culture, found that the number of shoots for the beans is higher in times of low rainfall intensity, and these results are similar to the bean crop of the present study in which leaf production was higher in soil water availability near $20 \%$ of the maximum capacity of soil water retention, compared values greater than $60 \%$.

Paiva (2007) found a decrease in the number of leaves of Java (Macrotyloma axillare) when subjected to low soil water availability. However, Bonfim-Silva et al. (2011b) found for millet the best leaf production in values ranging from 30 to $60 \%$ of field capacity. Bonfim-Silva et al. (2012) found the highest sorghum leaf production at 76 $\%$ of maximum soil water retention. It should be emphasized that millet and sorghum grasses are more susceptible to water stress conditions relative to leguminous vegetables such as pigeon pea. Maia (2005) cultivated the forest species gliricidia (Gliricidia sepium), jurema (Mimosa hostilis Benth) and neem (Azadirachta indica A. Juss.) in two soil types under conditions of water stress and found no statistical difference for plant growth variables, including the number of leaves. Thus, it can be noted that there is need for more studies on the best soil water availability when it comes to different species.

The dry weight of the shoots of pigeon pea was significantly influenced by soil water availability, fit to a quadratic regression model. The greatest dry shoot weight was observed in $59.02 \%$ of soil water availability (Figure 4). Soil water availability below or above this value presented reduced production of this variable for pigeon pea. According to Pimentel et al. (1999), water stress conditions reduce the rate of $\mathrm{CO}_{2}$ assimilation, thus negatively influencing the production of biomass. Freire et al. (2012) found a reduction in dry weight of shoots of Gliricidia when subjected to conditions of water stress, where water stress decreases the production of the plant assimilates (MATSUI; SINGH, 2003), reduces leaf water potential and decreases transpiration (KUMAR; SHARMA, 2009).

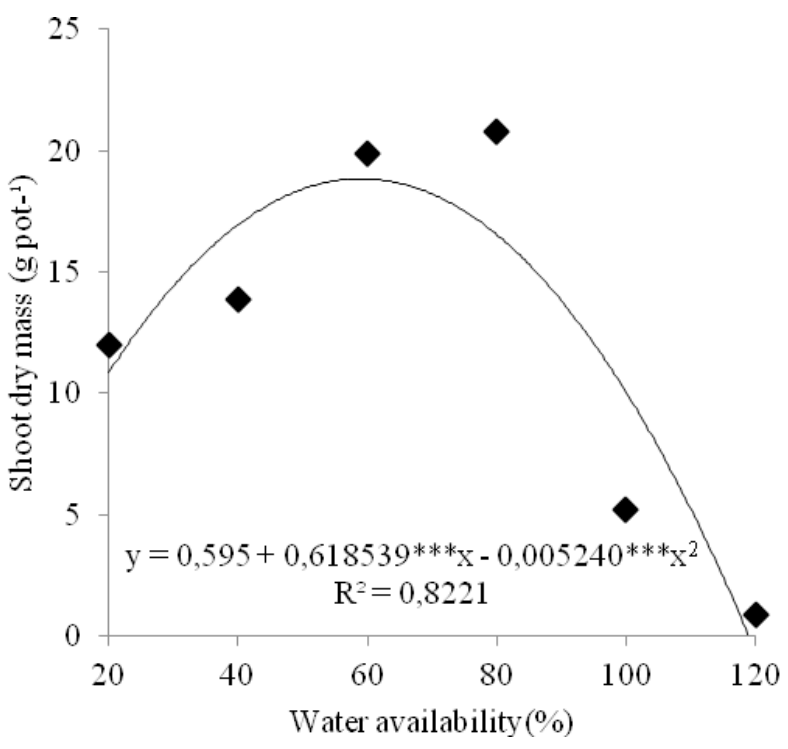

Figure 4. Dry mass of the shoots of pigeon pea cv. IAPAR 43 Aratã subjected to different levels of soil water availability. $* * *$ Significant at $0.1 \%$.

Bortolini et al. (2011) evaluated the morphological and physiological characteristics associated with drought tolerance in seven genotypes from the core collection of white clover, under the influence of soil water availability (40 and $90 \%$ of field capacity) and did not achieve statistical difference at availability of $40 \%$, but at availability of $90 \%$ there was no interaction of this variable with the chlorophyll content.

Bonfim-Silva et al. (2011a), cultivating three grasses (maize, millet and sorghum), found the highest dry shoot mass for the availability of $60 \%$. According to Marin et al. (2004), the dry weight production of pigeon pea is higher in conditions of low aluminum toxicity, but found no interaction of the dry shoot mass with soil water available for this crop, instead only for the analysis of the dry root weight.

According to Cesar et al. (2011), working with two cultivars of pigeon pea cv. Fava and cv. Anão, there was a significant difference among cultivars, where the production of total dry weight of $\mathrm{cv}$. Fava was $11.4 \mathrm{t} \mathrm{ha}^{-1}$ and for cv. Anão was $6.84 \mathrm{tha}^{-1}$ when cultured in times of higher soil water availability (spring/summer). This proves that the crop in the field is able to adapt better to severe conditions of water availability, which can easily be related to the infiltration of excess water to deeper soil layers. 
The root dry weight was fit to the quadratic regression model, where the greatest production was observed in $51.82 \%$ of soil water availability (Figure 5).

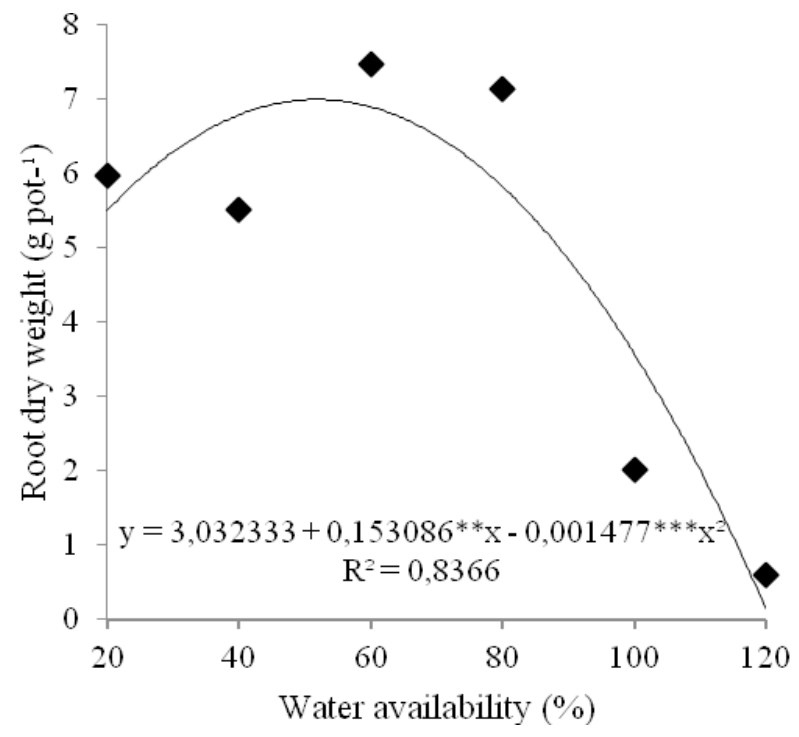

Figure 5. Root dry weight of pigeonpea cv. IAPAR 43 Aratã subjected to different levels of soil water availability. $* * *$ Significant at $0.1 \%$

Marin et al. (2004) studied levels of water availability from 0.0 to $-1.5 \mathrm{MPa}$ for cultivation of pigeon pea cv. IAPAR Aratã 43 and found that there was a marked decrease in root growth in osmotic potential $(0.0$ to $-0.9 \mathrm{MPa})$, and also that the higher osmotic potential $(-1.2$ to $-1.5 \mathrm{MPa})$, i.e., waterdeficit, inhibited the initial growth of the roots of IAPAR 43 Aratã. Ferreira et al. (2008) studied the physiological characteristics of maize under saturated conditions, emphasizing that stored water in the soil explored by the root system of the plants negatively influences morphological performance.

In general, it was observed in this study that the pigeon pea cv. IAPAR 43 Aratã showed less development of all variables when subjected to $100 \%$ of soil water availability and subject to saturation, the level of $120 \%$. However, when comparing the two extreme stress conditions, development was greater in water deficit (20 $\%$ of field capacity) compared to saturated soil. Water deficit is usually the most limiting factor for achieving high productivity and good quality products, but water in excess can also be harmful (SILVA;MAROUELLI, 1998).

Soil moisture controls the aeration, temperature and soil resistance, which are affected by soil density and size distribution of pores. These physical factors interact with and regulate the growth and functionality of the roots, reflected in the growth and crop yield (COLLARES et al., 2006) so that water fills the pore space reducing aeration with oxygen that reduces root development and in turn interferes the absorption of nutrients and affects microorganism survival.

Excess water in the soil can cause physiological stress in plants, showing poor growth and yellowing of leaves. Andrade and Valentine, (2008) likewise found when working at field capacity that the initial development of pigeonpea cv. IAPAR 43 Aratã did not show satisfactory results, where the best results were observed near $60 \%$ of the maximum capacity of soil water retention.

\section{CONCLUSIONS}

- The soil water availability that provides maximum soil $\mathrm{pH}$ is $80 \%$ of field capacity;

- The SPAD index is highest in the soil water available of $31.78 \%$ of field capacity;

- The pigeon pea grows best in soil water available in the range from 51.82 to $59.02 \%$ of field capacity.

\section{REFERENCES}

AKANDE, S.R. Genotype by environment interaction for cowpea seed yield and disease reactions in the forest and derived savanna agroecologies of south-west Nigeria. AmericanEurasian Journal of Agricultural \& Environmental Science, v.2, p.163-168, 2007.

ALCÂNTARA, F.A.et al. Adubação verde na recuperação da fertilidade de um Latossolo vermelho-escuro degradado. Pesquisa Agropecuária Brasileira, Brasília, v.35, p.277288, 2000.

ANDRADE, C.M.S.; VALENTIM, J.F. 
Desempenho agronômico do estilosantes campo grande no Acre. Rio Branco, AC: Embrapa Acre, 2008. 35p. (Embrapa Acre. Documentos, 111).

BASTOS, E.A.; RAMOS, H.M.M.; ANDRADE JUNIOR, A.S.; NASCIMENTO, F.N.; CARDOSO, M.J. Parâmetros fisiológicos e produtividade de grãos verdes do feijão-caupi sob déficit hídrico. Water Resources and Irrigation Management, Cruz das Almas, v.1, n.1, p.31-37, 2012.

BELTRAME, T.P.; RODRIGUES, E. Comparação de diferentes densidades de feijão guandu (Cajanus cajan (L.) Mill sp.) na restauração florestal de uma área de reserva legal no Pontaldo Paranapanema, SP. Scientia Forestalis, Piracicaba, v.36, n.80, p.317-327, 2008.

BONFIM-SILVA, E.M.; SILVA, T.J.A.; CABRAL, C.E.A.; KROTH, B.E.; RESENDE, D. Desenvolvimento inicial de gramíneas submetidas ao estresse hídrico. Revista Caatinga, Mossoró, v.24, n.2, p.180-186, 2011a.

BONFIM-SILVA, E.M.; SILVA, T.J.A.; CABRAL, C.E.A.; KROTH, B.E.; GUIMARÃES, S.L. Crescimento e produção de milheto em disponibilidades hídricas do solo. Enciclopédia Biosfera, Goiânia, v.7, n.12, p.1-8, 2011 b.

BONFIM-SILVA, E.M.; KROTH, B.E.; SILVA, T. J. A.; FREITAS, D.C. Disponibilidades hídricas no desenvolvimento inicial de sorgo e $\mathrm{pH}$ do solo. Enciclopédia Biosfera, Goiânia, v.8, n.14, p.397407, 2012.

BORTOLINI, F.; DALL'AGNOL, M.; BISSANI, C.A. Características morfofisiológicas associadas à tolerância à seca em sete genótipos da coleção nuclear de trevo branco. Ciência Rural, Santa Maria, v.41, n.9, p.1632-1638, 2011.

BUCHANAN, B.B.; GRUISSEM, W.; JONES, R.L. Biochemistry \& molecular biology of plants. Rockville: American Society of Plant Physiologists. 1408p. 2000.

CALEGARI, A.; MONDARDO, A.; BULIZANI, E.A.; COSTA, M.B.B.; MIYASAKA, S.;
AMADO, T.J. Aspectos gerais da adubação verde. In: COSTA, M.B.B.; CALEGARI, A.; MONDARDO, A.; BULIZANI, E.A.; WILDNER, L.P.; ALCÂNTRA, P.B.; MIYASAKA, S.; AMADO, T.J. Adubação verde no Sul do Brasil. $2^{\text {a }}$ Ed. Rio de Janeiro: AS-PTA, p.1-55. 1993.

CESAR, E.M.Z.; FUERRA, J.G.M.; RIBEIRO, R.L.D.; URQUIAGA, S.S.C.; PADOVAN, M.P. Performance de adubos verdes cultivados em duas épocas do ano no Cerrado do Mato Grosso do Sul. Revista Brasileira de Agroecologia, Cruz Alta, v.6, n.2, p.159-169. . 2011.

CARVALHO, A.M. Adubação verde e qualidade do solo no Cerrado. Embrapa Cerrados 2010. Disponível em: http://www.infoteca.cnptia. embrapa.br/bitstream/doc/875113/1/art061.pdf. Acesso em 07/11/2013.

CONAB - Companhia Nacional de Abastecimento. Acompanhamento de safra brasileira: grãos, sétimo levantamento, abril 2010 / Companhia Nacional de Abastecimento. Conab, p.54. 2010.

COLLARES, G.L.; REINERT, D.J.; REICHERT, J.M.; KAISER, D.R. Qualidade física do solo na produtividade da cultura do feijoeiro num Argissolo. Pesquisa Agropecuária Brasileira, v.41, n.11, p.1663-1674. 2006.

DIAS, M.M.; MACIEL, A.L.R.; ANUNCIAÇÃO, G.C.F. Avaliação da fertilidade do solo cultivado com cafeeiro cv. Rubi em consórcio com leguminosas na região sul de minas gerais. VII Simpósio de Pesquisa dos Cafés do Brasil 22 a 25 de Agosto, Araxá - MG. 2011.

EMBRAPA - Empresa Brasileira de Pesquisa Agropecuária. Manual de métodos de análises de solo. Centro Nacional de Levantamento e Conservação do Solo. Embrapa Solos. 1997.

FAGERIA, N.K.; BALIGAR, V.C.; EDWARD, D.G. Soil-Plant nutrient relationships at low $\mathrm{pH}$ stress. In: BALIGAR, V.C.; DUNCAN, R.R., ed. Crops as enhancers of nutrient use. Academic Press, New York. p.475-507. 1990. 
FAGERIA, N.K. Otimização da eficiência nutricional na produção das culturas. Revista Brasileira de Engenharia Agrícola e Ambiental, Campina Grande, v.2, p.6-16, 1998.

FERREIRA, D.F. SISVAR: um programa para análise e ensino de estatística. Revista Symposium, Lavras, v.3, p.317-345, 2008.

FERREIRA, J.L.; MAGALHÃES, P.C.; BORÉM, A. Avaliação de três características fisiológicas em 4 ciclos de seleção no cultivar de milho BRS-4154 sob solo encharcado. Ciência e Agrotecnologia, Lavras, v.32, n.6, p.1719-1723, 2008.

FREIRE, A.L.O; LEÃO, D.A.S.; Miranda, J.R.P. Acúmulo de massa seca e de nutrientes em gliricídia em resposta ao estresse hídrico e a doses de fósforo. Semina: Ciências Agrárias, Londrina, v.33, n.1, p.19-26, 2012.

KUMAR, A.; SHARMA, K.D. Physiological responses and dry matter partitioning of summer mungbean (Vigna radiata L.) genotypes subjected to drought conditions. Journal of Agronomy and Crop Science, Berlin, v.195, n.4, p.270-277, 2009.

LAL, R. Soil surface management in the tropics for intensive land use and high and sustained production. Advances in Soil Science, New York, v.5, p.1-109, 1986.

MAIA, E.L. Comportamento vegetativo de três espécies florestais sob estresse hídrico, com adubação orgânica em solos da região semiárida nordestina. Dissertação (Mestrado em Ciência do Solo: Área de Concentração em Manejo de Solo e Água) - Universidade Federal da Paraíba. 2005.

MATSUI, T.; SINGH, B.B. Roots characteristics in cowpea related to drought tolerance at the seedling stage. Experimental Agriculture, Cambridge, v.39, n.1, p.29-38. 2003.

MARIN, A.; SANTOS, D.M.M.; BANZATTO, D.A.; FERRAUDO, A.S. Germinação de sementes de guandu sob efeito da disponibilidade hídrica e de doses subletais de alumínio. Bragantia, Campinas, v.63, n.1, p.13-24, 2004.

MINOLTA CAMERA CO., Ltda. Manual for chlorophyll meter SPAD 502. Osaka, Minolta, Radiometric Instruments divisions. 1989. 22p.

MIZUBUTI, I.Y.; JUNIOR, O.B.; SOUZA, L.W.O.; SILVA, R.S.S.F.; IDA, E.I. Response surface methodology for extraction optimization of pigeon pea protein. Food Chemistry, London, v.70, p.259-265, 2000.

NENE, Y.L.; SHEILA,V.K. Pigeon pea: geography and importance. In: NENE, Y.; HALL, S.D.; SHEILA, V. (Ed.). The pigeon pea. Cambridge, Inglaterra: CAB International:1990. p.257-279.

OLIVEIRA, F.J.; ANUNCIAÇÃO FILHO, C.J.; BASTOS, G.Q.; REIS, O.V.; TEÓFILO, E.M. Caracteres agronômicos aplicados na seleção de cultivares de Caupi. Revista Ciência Agronômica, Fortaleza, v.34, n.1, p.5-11, 2003.

PAIVA, A.S. Disponibilidade hídrica na germinação de sementes e no crescimento de plântulas da leguminosa forrageira Macrotyloma axillare (E. Mey) Verde. cv. Java. 85f. Tese (Doutorado em Agronomia: Área de Concentração em Produção e Tecnologia de Sementes) Universidade Estadual Paulista, Campus de Jaboticabal, Jaboticabal, São Paulo. 2007.

PIMENTEL, C.; HÉBERT, G. Potencial fotossintético e condutância estomática em espécies de feijão caupi sob deficiência hídrica. Revista Brasileira de Fisiologia Vegetal, Campos dos Goytacazes, v.11, p.7-11, 1999.

SANTOS, A.M.; ROSA, L.M.G.; NABINGER, C.; FRANKE, L.B.; ABREU, J.B.R. Influência da orientação foliar e da disponibilidade hídrica na intercepção da radiação solar e no teor de clorofila da folha em Macroptilum lathyroides (L.) Urban1. Revista Univ. Rural, Série Ciências da Vida, Rio de Janeiro, EDUR. v.26, n.2, p.01-12. 2006.

SILVA, M.A.; SILVA, D.S.; LOPES, W.B.; 
ANDRADE, L.A. Fatores que explicam o número de folhas em plantas de feijão-bravo (Capparis flexuosa L.) no cariri paraibano. Revista Caatinga, Mossoró, v.22, n.2, p.144-148, 2009.

SILVA, W.L.C.; MAROUELLI, W.A. Manejo da irrigação em hortaliças no campo e em ambientes protegidos. In: FARIA, M.A. (Coord.) Manejo de irrigação Lavras: UFLA; SBEA. p.311-351, 1998.
SORATTO, R.P. Resposta do feijoeiro ao preparo do solo, manejo de água e parcelamento do nitrogênio. Acta Scientiarum: Agronomy, Maringá, v.25, n.1, p.89-96, 2003.

SOUSA, D.M.G.; LOBATO, E. Cerrado: correção do solo e adubação. Planaltina, DF: Embrapa Cerrados. 416p. 2002.

TAIZ, L.; ZEIGER, E. Fisiologia vegetal. 3.ed. Porto Alegre: Artmed, p.719. 2004. 